\title{
Aberrant activation of the mTOR pathway and anti-tumour effect of everolimus on oesophageal squamous cell carcinoma
}

\author{
K Hirashima',2, Y Baba', , M Watanabe', R-I Karashima', N Sato', Y Imamura', Y Nagai', N Hayashi', \\ K-I lyama ${ }^{2}$ and $\mathrm{H} \mathrm{Baba*,I}$
}

'Department of Gastroenterological Surgery, Graduate School of Medical Sciences, Kumamoto University, I-I - I Honjo, Kumamoto 860-8556, Japan; ${ }^{2}$ Department of Surgical Pathology, Kumamoto University Hospital, I - I-I Honjo, Kumamoto 860-8556, Japan

BACKGROUND: The mammalian target of rapamycin (mTOR) protein is important for cellular growth and homeostasis. The presence and prognostic significance of inappropriate $\mathrm{mTOR}$ activation have been reported for several cancers. Mammalian target of rapamycin inhibitors, such as everolimus (RAD00I), are in development and show promise as anti-cancer drugs; however, the therapeutic effect of everolimus on oesophageal squamous cell carcinoma (OSCC) remains unknown.

METHODS: Phosphorylation of mTOR (p-mTOR) was evaluated in 167 resected OSCC tumours and 5 OSCC cell lines. The effects of everolimus on the OSCC cell lines TE4 and TEII in vitro and alone or in combination with cisplatin on tumour growth in vivo were evaluated.

RESULTS: Mammalian target of rapamycin phosphorylation was detected in 116 tumours (69.5\%) and all the 5 OSCC cell lines. Everolimus suppressed p-mTOR downstream pathways, inhibited proliferation and invasion, and induced apoptosis in both TE4 and TEI I cells. In a mouse xenograft model established with TE4 and TEI I cells, everolimus alone or in combination with cisplatin inhibited tumour growth.

CONCLUSION: The mTOR pathway was aberrantly activated in most OSCC tumours. Everolimus had a therapeutic effect both as a single agent and in combination with cisplatin. Everolimus could be a useful anti-cancer drug for patients with OSCC.

British Journal of Cancer (2012) 1 06, 876-882. doi:I0.1038/bjc.2012.36 www.bjcancer.com

Published online 14 February 2012

(C) 2012 Cancer Research UK

Keywords: everolimus; RAD00 I; mTOR; oesophageal squamous cell carcinoma; proliferation

Oesophageal squamous cell carcinoma (OSCC), the major histological type of oesophageal cancer in East Asian countries, is one of the most aggressive malignant tumours (Enzinger and Mayer, 2003). Despite the development of multimodal therapies, including surgery, chemotherapy, and radiotherapy, the prognosis remains poor even for patients who undergo complete carcinoma resection. The limited improvement in outcomes achieved by conventional therapies urges us to seek innovative strategies, especially those involving molecular targeting, for treating OSCC.

The mammalian target of rapamycin (mTOR) is a $289-\mathrm{kDa}$ serine/threonine kinase involved in cellular growth and homeostasis (Bjornsti and Houghton, 2004; Abraham and Gibbons, 2007; Menon and Manning, 2008; Wouters and Koritzinsky, 2008). Mammalian target of rapamycin is activated by phosphorylation as a part of the phosphatidylinositol-3 kinase/AKT signalling pathway (Mita et al, 2003; Chan, 2004; Dancey, 2006) and in turn phosphorylates and activates eukaryotic translation factor $4 \mathrm{E}$ (elF4E) and p70 ribosomal S6 kinase (p70S6 kinase), leading to the translation of proteins required for cell cycle progression (Hidalgo and Rowinsky, 2000; Panwalkar et al, 2004). The presence and prognostic significance of aberrant mTOR activation have been reported for several types of human carcinomas (Easton and Houghton, 2006; Herberger et al, 2007; Hou et al, 2007; Hudes,

*Correspondence: Dr H Baba; E-mail: hdobaba@kumamoto-u.ac.jp Revised I0 January 20 I2; accepted II January 20 I2; published online I4 February 2012
2009; Hirashima et al, 2010). Our group previously showed an association between high phosphorylated mTOR (p-mTOR) expression and poor prognosis in 143 resected OSCC samples (Hirashima et al, 2010). Mammalian target of rapamycin has recently been recognised as an important and attractive target for anti-cancer therapy (Boulay et al, 2004; Bianco et al, 2006; Johnston, 2006; Antonarakis et al, 2010; Sparks and Guertin, 2010). Everolimus, an oral mTOR inhibitor, has shown particularly promising results in experimental studies, inhibiting tumour growth and displaying anti-angiogenic effects (Carmeliet and Jain, 2000; Bianco et al, 2008; Manegold et al, 2008; Lane et al, 2009). Combination therapy using everolimus and cisplatin has also been reported to be effective (Beuvink et al, 2005; Mabuchi et al, 2007; Hou et al, 2010; Ma et al, 2010). Many clinical trials using everolimus for several types of cancers are currently underway (Yee et al, 2006; Fouladi et al, 2007; Gridelli et al, 2007; Johnson et al, 2007; Awada et al, 2008; O'Donnell et al, 2008; Tabernero et al, 2008; Tanaka et al, 2008; Yao et al, 2008; Wolpin et al, 2009). Everolimus has been already approved for the treatment of advanced renal cell carcinoma in patients whose disease has progressed during or after VEGF-targeted therapy (Coppin, 2010). Nonetheless, to our knowledge, no study has examined the therapeutic effect of everolimus on OSCC using in vitro and in vivo assays.

We therefore conducted this study with three main aims. First, we examined the importance of mTOR activation in OSCC by determining the overall prevalence of $\mathrm{p}$-mTOR expression in OSCC 
specimens and cell lines. Second, we evaluated the therapeutic effect of everolimus on OSCC cell lines by both in vitro and in vivo assays. Third, we specifically assessed the effect of everolimus in combination with cisplatin, which is one of the most frequently used chemotherapeutic drugs, on OSCC cells.

\section{MATERIALS AND METHODS}

\section{Reagents and antibodies}

Everolimus was provided by Novartis Pharma AG (Basel, Switzerland) and formulated at $2 \%(\mathrm{w} / \mathrm{v})$ in a microemulsion vehicle. For in vivo analysis, everolimus was diluted to the appropriate concentration in double-distilled water just before administration by gavage. For in vitro analyses, everolimus was prepared in DMSO just before addition to cell cultures. Antibodies recognising mTOR, phospho-mTOR $\left(\mathrm{Ser}^{2448}\right)$, p70s6k, phospho-p70s6k $\left(\mathrm{Thr}^{389}\right)$, $4 \mathrm{E}-\mathrm{BP} 1$, phospho-4E-BP1 $\left(\mathrm{Thr}^{70}\right)$, and $\beta$-actin were purchased from Cell Signaling Technology (Boston, MA, USA).

\section{Patients}

The present study involved 167 consecutive patients who underwent surgical resection of OSCC at the Kumamoto University Hospital from January 1996 to December 2007. None of these patients underwent endoscopic mucosal resection, palliative resection, preoperative chemotherapy, preoperative radiotherapy, or preoperative chemoradiotherapy. This study was approved by the Institute Review Board of the Graduate School of Medical Science, Kumamoto University (Approval number: 236; 2 August 2008).

\section{Immunohistochemistry for $\mathrm{p}-\mathrm{mTOR}$}

The method of immunohistochemical staining for p-mTOR was described previously (Hirashima et al, 2010). Of the 167 tumours, 51 showed no p-mTOR expression, 84 showed weak expression, and 32 showed strong expression. As the aim of the immunohistochemistry in this study was to evaluate the prevalence of p-mTOR expression in OSCC tissues, both weak and strong p-mTOR expression were defined as positive.

\section{Cell culture}

Oesophageal squamous cell carcinoma cell lines (TE series) were obtained from the Cell Resource Center for Biomedical Research, Tohoku University. Cell cultures were grown in the recommended medium with $10 \%$ foetal bovine serum and incubated in $5 \% \mathrm{CO}_{2}$ at $37^{\circ} \mathrm{C}$.

\section{Western blot analysis}

Cultured cells were harvested and lysed in lysis buffer $(25 \mathrm{~mm}$ Tris$\mathrm{HCl}(\mathrm{pH} 7.4), 100 \mathrm{~mm} \mathrm{NaCl}, 2 \mathrm{~mm}$ EDTA, $1 \%$ Triton X-100, leupeptin, $1 \mathrm{mM} \mathrm{Na}_{3} \mathrm{VO}_{4}$, and $1 \mathrm{~mm}$ PMSF) for $30 \mathrm{~min}$. Lysates were centrifuged at $10000 \mathrm{rpm}$ for $5 \mathrm{~min}$ at $4{ }^{\circ} \mathrm{C}$. Each protein sample $(10 \mu \mathrm{g})$ was mixed with $5 \times$ sample buffer containing $10 \%$ $\beta$-mercaptoethanol and boiled for $5 \mathrm{~min}$. The total cellular protein extracts were separated by sodium dodecyl sulphate polyacrylamide gel electrophoresis (SDS-PAGE) on $7.5 \%$ gels for the examination of mTOR and p-mTOR, and on $12.5 \%$ gels for the examination of $\mathrm{p} 70 \mathrm{~S} 6 \mathrm{~K}, \mathrm{p}-\mathrm{p} 70 \mathrm{~S} 6 \mathrm{~K}, 4 \mathrm{E}-\mathrm{BP} 1, \mathrm{p}-4 \mathrm{E}-\mathrm{BP} 1$, and $\beta$-actin. The samples were then transferred to PVDF membranes (Bio-Rad, Hercules, CA, USA), which were blocked overnight at $4{ }^{\circ} \mathrm{C}$ in $5 \%$ skim milk in phosphate-buffered saline (PBS) containing $0.1 \%$ Tween 20. The membranes were probed overnight at $4{ }^{\circ} \mathrm{C}$ with each primary monoclonal antibody followed by incubation with peroxidase-conjugated anti-rat IgG antibody (1:1000) (Sigma,
St Louis, MO, USA). The targets were detected using an enhanced chemiluminescence (ECL) reagent (GE Healthcare, Piscataway, NJ, USA).

\section{Cell proliferation analysis}

The effect of everolimus on cell proliferation was evaluated using a water-soluble tetrazolium salt (WST-8; (2-(2-methoxy-4-nitrophenyl)-3-(4-nitrophenyl)-5-(2, 4-disulfophenyl)-2H-tetrazolium, monosodium salt) (Dojin Chemicals, Tokyo, Japan). TE4 and TE11 cells were cultured overnight in 96 -well plates $\left(3 \times 10^{3}\right.$ cells per well). Cells were then treated for $48 \mathrm{~h}$ with everolimus ( $20 \mathrm{~nm}$ ) or vehicle (control) and their viabilities were assessed. The number of surviving cells in each sample was determined from its absorbance at $450 \mathrm{~nm}\left(\mathrm{~A}_{450}\right)$.

\section{Cell cycle analysis}

The cell cycle distribution of TE4 and TE11 cells treated with everolimus ( $20 \mathrm{~nm}$ ) or vehicle (control) for $48 \mathrm{~h}$ was analysed by flow cytometry using a BD FACSCalibur (BD Bioscience, San Jose, CA, USA) according to previously published methods (Del Bufalo et al, 2004; Milella et al, 2004).

\section{Apoptosis analysis}

TE4 and TE11 cells were treated with everolimus ( $20 \mathrm{nM})$ or vehicle (control) for $48 \mathrm{~h}$ and then apoptosis was assessed by flow cytometry using Annexin V-FITC (BD Bioscience) and propidium iodide (PI) staining according to previously published methods (Del Bufalo et al, 2004; Milella et al, 2004).

\section{Invasion analysis}

To evaluate the effect of everolimus on cell invasiveness, a Matrigel Invasion Chamber (BD Bioscience) was used according to the manufacturer's protocol. Matrigel-coated chambers containing $8 \mu \mathrm{m}$ pore-size filters were fitted into 24 -well tissue culture plates. Briefly, cells of each type (TE4, $1.0 \times 10^{5}$ cells ml $^{-1}$; TE11, $5.0 \times 10^{5}$ cells $\mathrm{ml}^{-1}$ ) were seeded into the Matrigel-coated chambers in RPMI-1640 medium with everolimus (20 nM) or vehicle (control) and incubated at $37^{\circ} \mathrm{C}$ in $5 \% \mathrm{CO}_{2}$ for $24 \mathrm{~h}$. The invasive cells on the bottom sides of the filters were stained using Toruijin blue dye, and the numbers of cells in five randomly selected fields at $\times 200$ magnification were counted.

\section{Subcutaneous xenograft model}

All the procedures involving animals and their care were approved by the Animal Care and Use Committee of Kumamoto University. These procedures meet the standards required by the United Kingdom Coordinating Committee for Cancer Research (UKCCCR) guidelines (Workman et al, 2010). A subcutaneous xenograft model was used to assess the therapeutic effect on OSCC cells of everolimus either as a single agent or in combination with cisplatin, one of the chemotherapeutic drugs most frequently used for OSCC in the clinical setting. Six-week-old nude mice (BALB/c) $(n=24)$ were inoculated subcutaneously in the right or left flank with $5 \times 10^{6}$ TE4 cells and TE1 1 cells in $200 \mu$ l of PBS. Some mice showed insufficient tumour growth and were therefore excluded from the study, leaving a total of 22 mice used for the single in vivo experiment. When the tumours reached approximately $50-70 \mathrm{~mm}^{3}$, the mice were randomised into four treatment groups ( $n=5-6$ mice per group). The first group was treated twice a week with placebo. The second group was treated twice a week with everolimus $\left(5 \mathrm{mg} \mathrm{kg}^{-1}\right)$. The third group was treated every 2 weeks with cisplatin $\left(3 \mathrm{mg} \mathrm{kg}^{-1}\right)$. The fourth group was treated twice a week with everolimus $\left(5 \mathrm{ml} \mathrm{kg}^{-1}\right)$ and every 2 weeks with cisplatin 
A

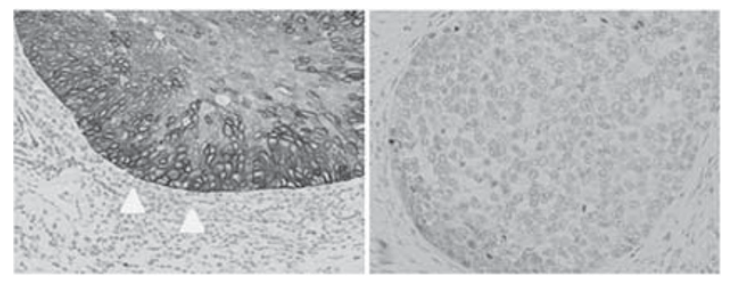

c

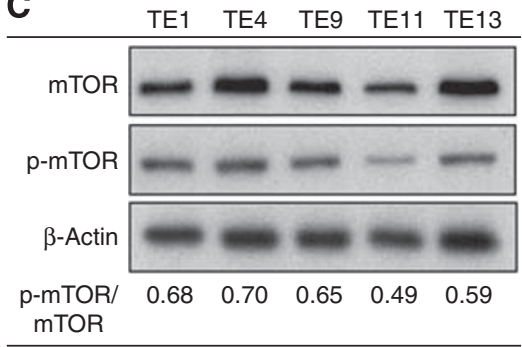

Figure I Immunostaining for p-mTOR. (A) Oesophageal squamous cell cancer cells positive for p-mTOR (white arrow). (B) Oesophageal squamous cell cancer cells negative for p-mTOR. (C) Western blot analysis of mTOR, p-mTOR, and $\beta$-actin levels in TEI, 4, 9, II, and I3 cell lines.

$\left(3 \mathrm{mg} \mathrm{kg}^{-1}\right)$ (Figure $\left.4 \mathrm{~A}\right)$. The validity of these everolimus and/or cisplatin protocols has been demonstrated in an ovarian cancer model. Everolimus was administered by oral gavage using an animal-feeding needle. Cisplatin was injected intraperitoneally. Body weight was measured every 3 days. Calliper measurements of the longest perpendicular tumour diameters were made weekly using a digital calliper, and tumour volumes were estimated using the following formula: $V=L \times W \times D \times \pi / 6$, where $V$ is the tumour volume, $L$ the length, $W$ the width, and $D$ the depth (Mabuchi et al, 2007).

\section{Statistical analysis}

For the in vitro assays, including the cell proliferation assay, cell cycle ratio assay, apoptosis assay, and invasion assay, statistical analyses were performed using Mann-Whitney's $U$-test for unpaired samples. For the in vivo experiment, body weight and tumour volume were compared among placebo-, everolimus-, cisplatin-, and everolimus plus cisplatin-treated mice using the Wilcoxon exact test. Statistical analysis was performed with Stat View-J 5.0 software (Abacus Concepts, Inc., Berkeley, CA, USA). A two-sided significance level of $P<0.05$ was used for all the statistical analyses.

\section{RESULTS}

\section{Phosphorylated mTOR expression in OSCC specimens and cell lines}

We assessed p-mTOR expression (i.e., mTOR activation) by immunohistochemistry. Of the 167 OSCC specimens, $116(70 \%)$ were positive for $\mathrm{p}$-mTOR expression (Figures $1 \mathrm{~A}$ and $\mathrm{B}$ ). The high percentage of p-mTOR-positive tumours supports the crucial role of mTOR activation in the pathogenesis of OSCC.

All five human OSCC cell lines (TE1, 4, 9, 11, and 13) examined in the current study showed p-mTOR expression in vitro; the expression level was highest in TE4 cells and lowest in TE11 cells (Figure 1C). Therefore, both TE4 and TE11 cells were used in the following experiments.

\section{Everolimus attenuates phosphorylation of p70S6K and 4E-BP1 in vitro}

The TE4 and TE11 cells were treated with different concentrations of everolimus ( 0 (vehicle control), $0.2,2$, and $20 \mathrm{nM}$ ) and the levels and phosphorylation of downstream mTOR targets, including p70S6k, p-p70S6k, 4E-BP1, p-4E-BP1, and $\beta$-actin (loading control), were evaluated by western blotting. Everolimus inhibited phosphorylation of p70S6k and 4E-BP1 (decreased levels of p-p70S6k and p-4E-BP1) in TE4 cells in a dose-dependent manner (Figure 2). In TE11 cells, $20 \mathrm{~nm}$ everolimus was sufficient to block phosphorylation of p70S6k and 4E-BP1 (Figure 2). Therefore, TE4 and TE11 cell lines were treated with $20 \mathrm{~nm}$ everolimus in the

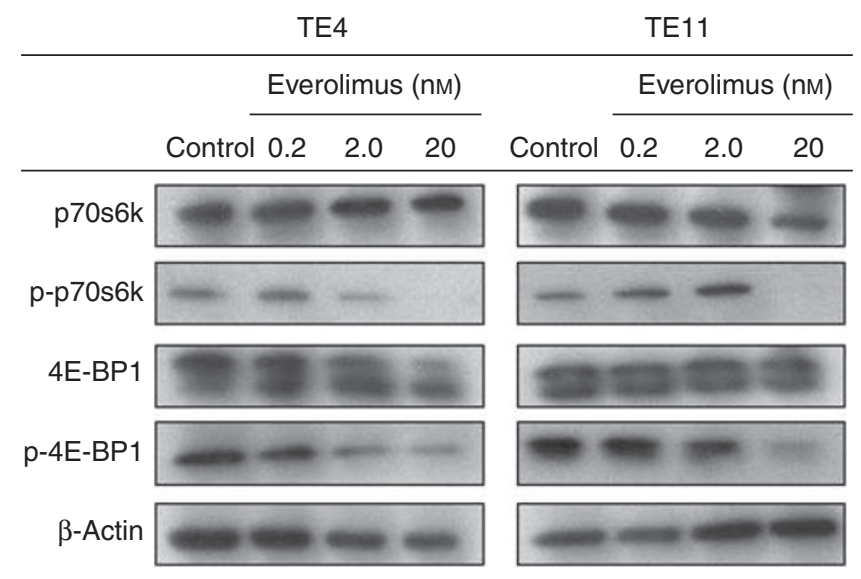

Figure 2 Western blot analysis for p70S6k, p-p70S6k, 4E-BPI p-4E-BPI, and $\beta$-actin protein levels in TE4 and TEII cells treated with (at indicated concentrations) or without everolimus.

following assays (e.g., the in vitro proliferation, cell cycle, apoptosis, and invasion assays).

\section{Therapeutic effect of everolimus on OSCC cell lines in vitro}

Everolimus (20 nM) treatment for $48 \mathrm{~h}$ significantly inhibited the proliferation of both TE4 and TE11 cells (Figure 3A). In order to clarify the effect of everolimus on the cell cycle, OSCC cells were treated with everolimus ( $20 \mathrm{~nm})$ and then subjected to cell cycle analysis by flow cytometry. An accumulation of cells in the $G_{0} / G_{1}$ phase and a reduction in the $\mathrm{S}$-phase fraction were observed in both TE4 and TE11 cells treated with everolimus ( $20 \mathrm{nM}$ ) for $48 \mathrm{~h}$ (Figure $3 \mathrm{~B})$. Everolimus $(20 \mathrm{~nm})$ also significantly increased the proportion of early apoptotic cells (Annexin V-FITC positive, PI negative) compared with that of vehicle-treated cells in both TE4 and TE11 cells treated for $48 \mathrm{~h}$ (Figure 3C), indicating that everolimus could induce early apoptosis in these cell lines. Western blot analysis utilising antibodies for Bad and PARP also showed the induction of apoptosis by everolimus (Supplementary Figure 1); everolimus (20 nM) increased the expression of Bad and cleaved PARP protein. Finally, we performed an in vitro invasion assay using Matrigel Invasion Chambers and found that everolimus (20 nM) significantly decreased the numbers of invading TE4 and TE11 cells compared with those of vehicle-treated cells (Figure 3D).

\section{Everolimus inhibits tumour growth in a mouse subcutaneous xenograft model}

The mean tumour volumes on day 36 in a mouse xenograft model established with TE4 cells were $1314 \pm 134,311 \pm 87,542 \pm 161$, and 
A

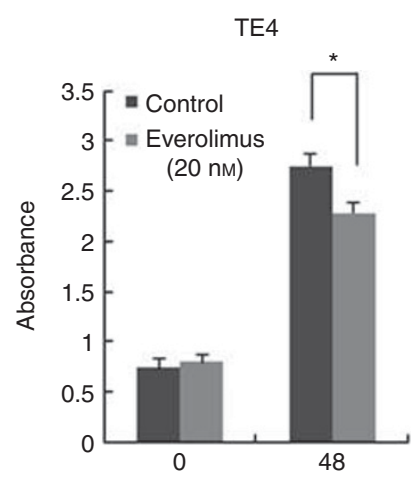

Hours after start of treatment

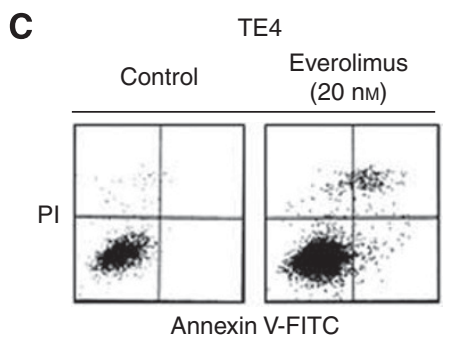

Annexin V-FITC

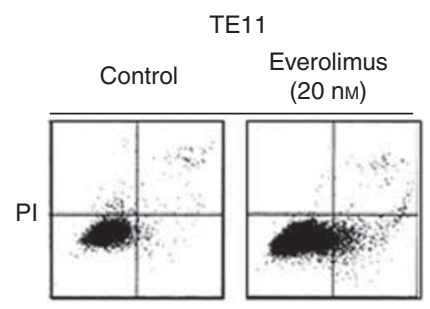

Annexin V-FITC

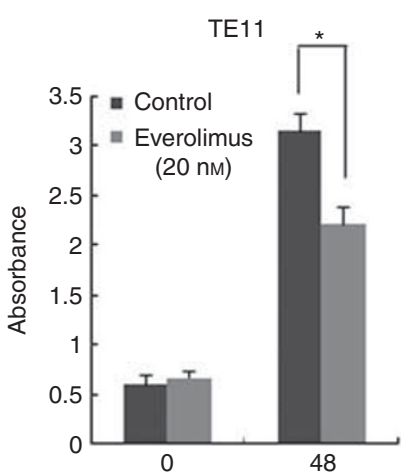

Hours after start of treatment
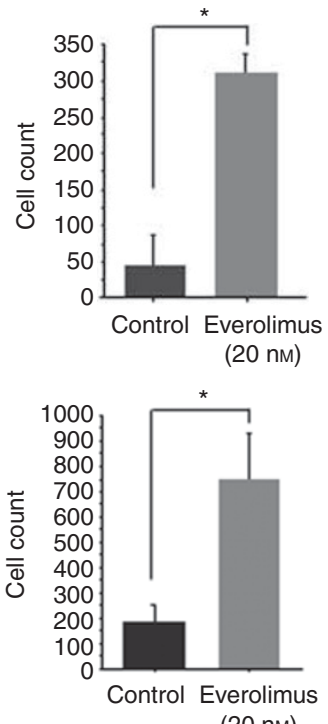

B

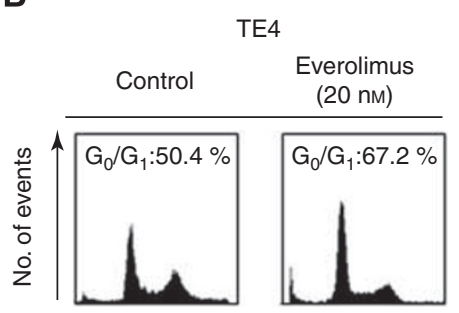

TE11
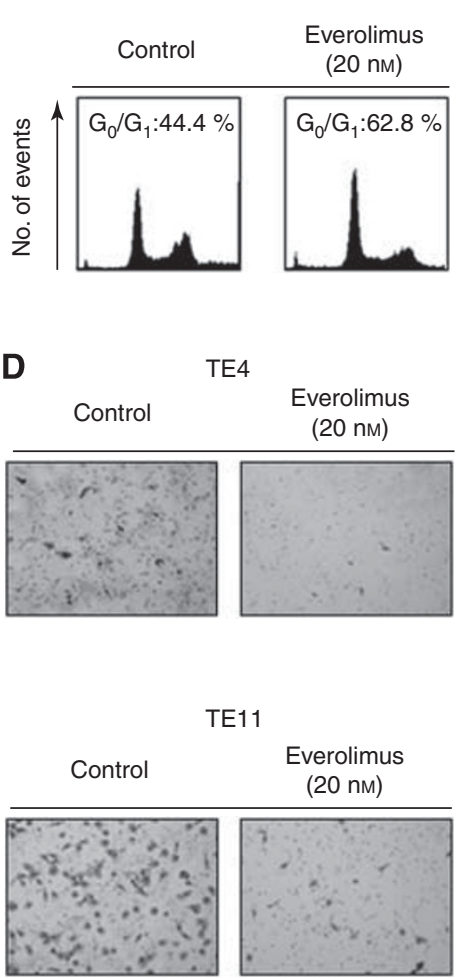

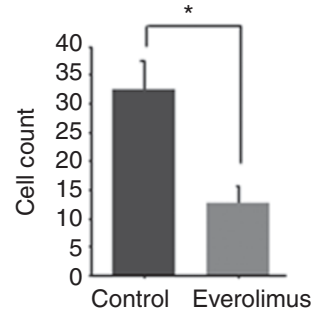

(20 nм)

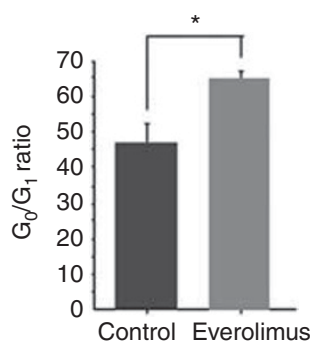

(20 nm)

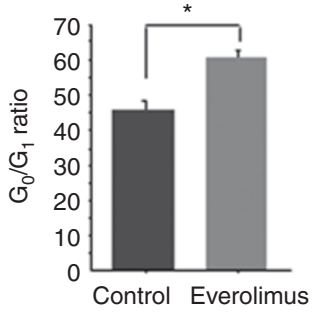

(20 nm)

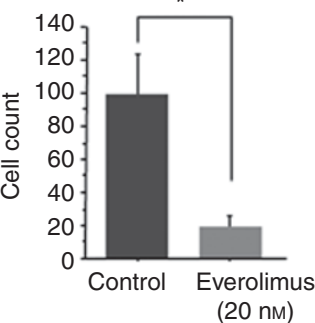

Figure 3 In vitro assay for confirming the anti-cancer activity of everolimus. (A) In vitro proliferation assay. Treatment with everolimus (20 nm) for $48 \mathrm{~h}$ decreased the proliferation ratios of both TE4 and TEI I cells compared with those of control vehicle-treated cells. *P<0.05. (B) In vitro cell cycle assay. Treatment with everolimus $(20 \mathrm{nM})$ increased the percentages of TE4 and TEI I cells in $\mathrm{G}_{0} / \mathrm{G}_{\text {I }}$ phase compared with those of control vehicle-treated cells. ${ }^{*} \mathrm{P}<0.05$. (C) In vitro cell apoptosis analysis. Induction of early apoptosis in TE4 and TEI I cells by everolimus is shown (lower right part; Annexin $\mathrm{V}$-FITCpositive, Pl-negative). (D) In vitro invasion assay. Everolimus (20 nM) decreased the numbers of invading TE4 and TEI I cells compared with those of control vehicle-treated cells ( $\times 200$ magnification, five fields). $* P<0.05$

Table I Effect of everolimus on tumour development of TE4 cell lines

\begin{tabular}{lccc}
\hline Treatment & $\begin{array}{c}\text { Number } \\
\text { of } \mathbf{m i c e}\end{array}$ & $\begin{array}{c}\text { Mean tumour } \\
\text { volume } \mathbf{( m m}^{\mathbf{3}} \mathbf{)}\end{array}$ & $\begin{array}{c}\text { \% Effect of } \\
\text { tumour } \\
\text { reduction }\end{array}$ \\
\hline Placebo & 6 & $1314 \pm 134$ & 100 \\
Everolimus & 5 & $311 \pm 87 * \dagger$ & 23 \\
Cisplatin & 5 & $542 \pm 161^{*}$ & 41 \\
Everolimus+cisplatin & 6 & $159 \pm 21^{*},+$ & 12 \\
\hline
\end{tabular}

*Significantly different from the placebo group $(P<0.05) .{ }^{\dagger}$ Significantly different from the cisplatin group $(P<0.05)$. ${ }^{\ddagger}$ Significantly different from the everolimus group $(P<0.05)$.

$159 \pm 21 \mathrm{~mm}^{3}$ in mice treated with placebo, everolimus, cisplatin, and everolimus plus cisplatin, respectively (Table 1, Figure 4B). Treatment with everolimus or cisplatin alone decreased the tumour burdens by $83 \%$ and $68 \%$, respectively, compared with that of placebo-treated mice (Figure 4C), indicating that everolimus used as a single agent has marked anti-tumour activity. Moreover, treatment with cisplatin plus everolimus decreased the tumour burden by $92 \%$ (Figure $4 \mathrm{C}$ ), suggesting that the use of everolimus and cisplatin as a combination therapy might be promising. Similar results were obtained for TE11 cells (Supplementary Figure 2).

The weight changes of the mice over the course of the treatments did not differ significantly among the four groups, as shown in Supplementary Figure 3. In addition, we confirmed histologically that there were no differences in the levels of injury to the organs, including liver, kidney, pancreas, lung, intestine, and skin, among these four groups (Supplementary Figure 4). We continued to follow these mice for 2 months. Although all of the mice in the placebo group died within 2 months, no mouse in any of the other three groups died during this period. 


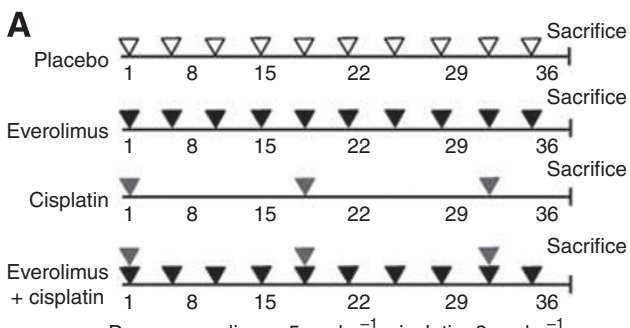

Doses; everolimus, $5 \mathrm{mg} \mathrm{kg}^{-1}$; cisplatin, $3 \mathrm{mg} \mathrm{kg}^{-1}$

\section{B}

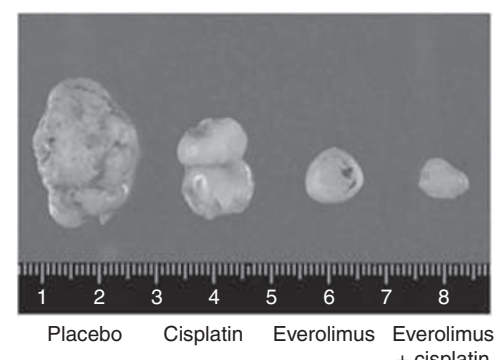

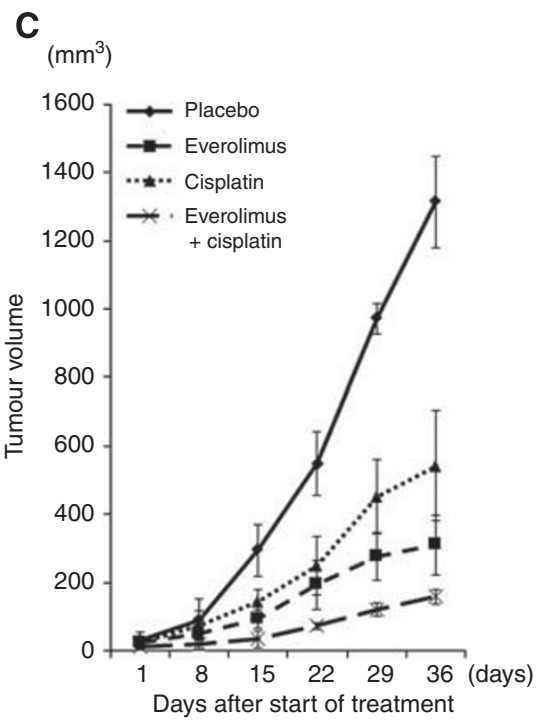

Figure 4 In vivo assay for confirming the anti-cancer activity of everolimus utilising a mouse xenograft model established with TE4 cells. (A) Treatment schedules for the four treatment groups (placebo, everolimus, cisplatin, and everolimus plus cisplatin). (B) Tumour volume in the four treatment groups (placebo, everolimus, cisplatin, and everolimus plus cisplatin) after the 5-week course of treatment. (C) Growth of tumour volume in the four treatment groups.

\section{DISCUSSION}

Mammalian target of rapamycin is a key regulator of cell growth and proliferation and as such is regarded as a promising target for anti-cancer therapy (Kapoor, 2009; Scott et al, 2009). In this study, we made three intriguing findings. First, most OSCC tumours were positive for p-mTOR expression, supporting a role for mTOR activation in the pathogenesis of OSCC. Second, everolimus, an oral mTOR inhibitor, had a therapeutic effect on OSCC cell lines in vitro. Third, combination therapy with everolimus and cisplatin showed an additive effect on OSCC cells in vivo. Our findings certainly suggest that everolimus could be useful as an anti-cancer drug for patients with OSCC.

Previous studies have shown the importance of mTOR activation in OSCC specimens: Boone et al, (2008) detected activated mTOR in $25 \%$ of patients with OSCC, a subset of patients that might potentially benefit from mTOR-inhibiting therapy. Yoshioka et al, (2008) demonstrated that $48 \%$ of OSCC tumours showed high levels of p-mTOR phosphorylation. In the current study utilising 167 OSCC samples, about $70 \%$ of the OSCC tumours showed p-mTOR (i.e., mTOR activation). This discrepancy might be due to a difference in the method used to evaluate mTOR phosphorylation or in the cutoff for p-mTOR positivity. Nonetheless, these two previous studies and the current study certainly support the hypotheses that mTOR activation is important in the pathogenesis of OSCC and that mTOR inhibitors might be useful for OSCC treatment.

Everolimus, an orally bioavailable derivative of rapamycin, is a promising drug for cancer therapy. However, to our knowledge, no previous study has utilised in vitro and in vivo models to evaluate the therapeutic efficacy of everolimus. First, we demonstrated that everolimus suppressed down-stream signalling (i.e., phosphorylation of p70s6 kinase and 4E-BP1) and significantly inhibited cell proliferation and invasion of mTOR-activated OSCC cell lines in vitro. Second, we showed that inhibition of mTOR signalling by everolimus induced $G_{0} / G_{1}$ arrest and apoptosis, suggesting that everolimus might inhibit anti-apoptotic or survival signalling in OSCC cell lines. Third, we found that treatment with everolimus significantly inhibited tumour growth in vivo. Taken together, these results indicate that everolimus as a single agent could have significant anti-tumour efficacy against OSCC cells.
The effects of everolimus were more prominent in TE11 cells (p-mTOR-low) than in TE4 cells (p-mTOR-high). The malignant characteristics of OSCC cells are likely acquired not only through the mTOR signalling pathway but also through a wide variety of other signalling pathways. Although the activation level of the mTOR pathway was lower in TE11 cells than in TE4 cells, TE11 cells might depend more heavily on the mTOR pathway for their malignant behaviour. On the other hand, although TE4 cells showed a high level of mTOR activation, they might rely more on the other signalling pathways than on the mTOR pathway. In this study, the mTOR pathway was activated in all five cell lines assessed. If we could obtain an OSCC cell line without mTOR activation, those cells might well be resistant to everolimus. Future studies are necessary to confirm our findings as well as to elucidate the biological mechanisms by which the mTOR activation level affects the therapeutic efficacy of everolimus.

Interestingly, we also found an additive effect of everolimus and cisplatin on OSCC cells in an in vivo model. A similar effect has been reported for other types of carcinomas. Beuvink et al, (2005) reported that everolimus could sensitise cells to cisplatin by inhibiting induction of p21 expression by p53. Ma et al, (2010) showed that everolimus exerts an additive-to-synergetic effect on cisplatin-induced growth inhibition in nasopharyngeal carcinoma. Unfortunately, our current experiment could show only an additive effect rather than a synergetic effect. We expect that additional experiments in the future might be able to show a synergetic effect. However, we were at least able to recognise that combining everolimus and cisplatin might be a useful therapeutic strategy. As cisplatin is one of the most important chemotherapeutic drugs for OSCC treatment, our finding may have significant clinical implications.

In conclusion, most OSCC tumours showed mTOR activation, suggesting that mTOR could be a promising target for anti-cancer therapy against OSCC. Everolimus had a therapeutic effect on OSCC cells both in vitro and in vivo, and combination therapy with everolimus and cisplatin showed an additive effect. Although further experimental studies are necessary to confirm our findings, the current study certainly provides further rationale for future clinical trials of everolimus (in combination with cisplatin) in OSCC patients. 


\section{ACKNOWLEDGEMENTS}

This work was made possible by the provision of everolimus (RAD001) by Novartis Pharma AG (Basel, Switzerland). We thank Novartis Pharma AG for their kindness. We thank Dr Katsunori Imai and Keisuke Miyake for in vitro technical assistance, and Dr Satoshi Ida and Dr Hasta Holrad for in vivo technical assistance. The content is solely the responsibility of the authors and does not necessarily represent the official views of the NCI or NIH. The funders had no role in the study design, data collection and analysis, decision to publish, or preparation of the manuscript.

\section{Conflict of interest}

The authors declare no conflict of interest.

Supplementary Information accompanies the paper on British Journal of Cancer website (http://www.nature.com/bjc)

\section{REFERENCES}

Abraham RT, Gibbons JJ (2007) The mammalian target of rapamycin signaling pathway: twists and turns in the road to cancer therapy. Clin Cancer Res 13: 3109-3114

Antonarakis ES, Carducci MA, Eisenberger MA (2010) Novel targeted therapeutics for metastatic castration-resistant prostate cancer. Cancer Lett 291: 1-13

Awada A, Cardoso F, Fontaine C, Dirix L, De Greve J, Sotiriou C, Steinseifer J, Wouters C, Tanaka C, Zoellner U, Tang P, Piccart M (2008) The oral mTOR inhibitor RAD001 (everolimus) in combination with letrozole in patients with advanced breast cancer: results of a phase I study with pharmacokinetics. Eur J Cancer 44: 84-91

Beuvink I, Boulay A, Fumagalli S, Zilbermann F, Ruetz S, O'Reilly T, Natt F, Hall J, Lane HA, Thomas G (2005) The mTOR inhibitor RAD001 sensitizes tumor cells to DNA-damaged induced apoptosis through inhibition of p21 translation. Cell 120: 747-759

Bianco R, Garofalo S, Rosa R, Damiano V, Gelardi T, Daniele G, Marciano R, Ciardiello F, Tortora G (2008) Inhibition of mTOR pathway by everolimus cooperates with EGFR inhibitors in human tumours sensitive and resistant to anti-EGFR drugs. $\mathrm{Br} J$ Cancer 98: $923-930$

Bianco R, Melisi D, Ciardiello F, Tortora G (2006) Key cancer cell signal transduction pathways as therapeutic targets. Eur J Cancer 42: 290-294

Bjornsti MA, Houghton PJ (2004) The TOR pathway: a target for cancer therapy. Nat Rev Cancer 4: 335-348

Boone J, Ten Kate FJ, Offerhaus GJ, van Diest PJ, Rinkes $\mathrm{IH}_{\text {, }}$ van Hillegersberg R (2008) mTOR in squamous cell carcinoma of the oesophagus: a potential target for molecular therapy? J Clin Pathol 61: 909-913

Boulay A, Zumstein-Mecker S, Stephan C, Beuvink I, Zilbermann F, Haller R, Tobler S, Heusser C, O'Reilly T, Stolz B, Marti A, Thomas G, Lane HA (2004) Antitumor efficacy of intermittent treatment schedules with the rapamycin derivative RAD001 correlates with prolonged inactivation of ribosomal protein S6 kinase 1 in peripheral blood mononuclear cells. Cancer Res 64: 252-261

Carmeliet P, Jain RK (2000) Angiogenesis in cancer and other diseases. Nature 407: 249-257

Chan S (2004) Targeting the mammalian target of rapamycin (mTOR): a new approach to treating cancer. Br J Cancer 91: 1420 - 1424

Coppin C (2010) Everolimus: the first approved product for patients with advanced renal cell cancer after sunitinib and/or sorafenib. Biologics 4: $91-101$

Dancey JE (2006) Therapeutic targets: MTOR and related pathways. Cancer Biol Ther 5: $1065-1073$

Del Bufalo D, Trisciuoglio D, Scarsella M, D’Amati G, Candiloro A, Iervolino A, Leonetti C, Zupi G (2004) Lonidamine causes inhibition of angiogenesis-related endothelial cell functions. Neoplasia 6: 513-522

Easton JB, Houghton PJ (2006) mTOR and cancer therapy. Oncogene 25: 6436-6446

Enzinger PC, Mayer RJ (2003) Esophageal cancer. N Engl J Med 349: $2241-2252$

Fouladi M, Laningham F, Wu J, O'Shaughnessy MA, Molina K, Broniscer A, Spunt SL, Luckett I, Stewart CF, Houghton PJ, Gilbertson RJ, Furman WL (2007) Phase I study of everolimus in pediatric patients with refractory solid tumors. J Clin Oncol 25: 4806-4812

Gridelli C, Rossi A, Morgillo F, Bareschino MA, Maione P, Di Maio M, Ciardiello F (2007) A randomized phase II study of pemetrexed or RAD001 as second-line treatment of advanced non-small-cell lung cancer in elderly patients: treatment rationale and protocol dynamics. Clin Lung Cancer 8: $568-571$
Herberger B, Puhalla H, Lehnert M, Wrba F, Novak S, Brandstetter A, Gruenberger B, Gruenberger T, Pirker R, Filipits M (2007) Activated mammalian target of rapamycin is an adverse prognostic factor in patients with biliary tract adenocarcinoma. Clin Cancer Res 13: $4795-4799$

Hidalgo M, Rowinsky EK (2000) The rapamycin-sensitive signal transduction pathway as a target for cancer therapy. Oncogene 19: 6680-6686

Hirashima K, Baba Y, Watanabe M, Karashima R, Sato N, Imamura Y, Hiyoshi Y, Nagai Y, Hayashi N, Iyama K, Baba H (2010) Phosphorylated mTOR expression is associated with poor prognosis for patients with esophageal squamous cell carcinoma. Ann Surg Oncol 17: 2486-2493

Hou G, Xue L, Lu Z, Fan T, Tian F, Xue Y (2007) An activated mTOR/ p70S6K signaling pathway in esophageal squamous cell carcinoma cell lines and inhibition of the pathway by rapamycin and siRNA against mTOR. Cancer Lett 253: 236-248

Hou G, Zhang Q, Wang L, Liu M, Wang J, Xue L (2010) mTOR inhibitor rapamycin alone or combined with cisplatin inhibits growth of esophageal squamous cell carcinoma in nude mice. Cancer Lett 290: $248-254$

Hudes GR (2009) Targeting mTOR in renal cell carcinoma. Cancer 115: $2313-2320$

Johnson BE, Jackman D, Janne PA (2007) Rationale for a phase I trial of erlotinib and the mammalian target of rapamycin inhibitor everolimus (RAD001) for patients with relapsed non small cell lung cancer. Clin Cancer Res 13: s4628 - s4631

Johnston SR (2006) Clinical efforts to combine endocrine agents with targeted therapies against epidermal growth factor receptor/human epidermal growth factor receptor 2 and mammalian target of rapamycin in breast cancer. Clin Cancer Res 12: 1061 -108s

Kapoor A (2009) Inhibition of mTOR in kidney cancer. Curr Oncol 16(Suppl 1): S33-S39

Lane HA, Wood JM, McSheehy PM, Allegrini PR, Boulay A, Brueggen J, Littlewood-Evans A, Maira SM, Martiny-Baron G, Schnell CR, Sini P, O'Reilly T (2009) mTOR inhibitor RAD001 (everolimus) has antiangiogenic/vascular properties distinct from a VEGFR tyrosine kinase inhibitor. Clin Cancer Res 15: 1612 - 1622

Ma BB, Lui VW, Hui EP, Lau CP, Ho K, Ng MH, Cheng SH, Tsao SW, Chan AT (2010) The activity of mTOR inhibitor RAD001 (everolimus) in nasopharyngeal carcinoma and cisplatin-resistant cell lines. Invest New Drugs 28: $413-420$

Mabuchi S, Altomare DA, Cheung M, Zhang L, Poulikakos PI, Hensley HH, Schilder RJ, Ozols RF, Testa JR (2007) RAD001 inhibits human ovarian cancer cell proliferation, enhances cisplatin-induced apoptosis, and prolongs survival in an ovarian cancer model. Clin Cancer Res 13: $4261-4270$

Manegold PC, Paringer C, Kulka U, Krimmel K, Eichhorn ME, Wilkowski R, Jauch KW, Guba M, Bruns CJ (2008) Antiangiogenic therapy with mammalian target of rapamycin inhibitor RAD001 (Everolimus) increases radiosensitivity in solid cancer. Clin Cancer Res 14: 892-900

Menon S, Manning BD (2008) Common corruption of the mTOR signaling network in human tumors. Oncogene 27(Suppl 2): S43-S51

Milella M, Trisciuoglio D, Bruno T, Ciuffreda L, Mottolese M, Cianciulli A, Cognetti F, Zangemeister-Wittke U, Del Bufalo D, Zupi G (2004) Trastuzumab down-regulates Bcl-2 expression and potentiates apoptosis induction by Bcl-2/Bcl-XL bispecific antisense oligonucleotides in HER-2 gene-amplified breast cancer cells. Clin Cancer Res 10: 7747-7756

Mita MM, Mita A, Rowinsky EK (2003) The molecular target of rapamycin (mTOR) as a therapeutic target against cancer. Cancer Biol Ther 2: S169-S177 
O'Donnell A, Faivre S, Burris 3rd HA, Rea D, Papadimitrakopoulou V, Shand N, Lane HA, Hazell K, Zoellner U, Kovarik JM, Brock C, Jones S, Raymond E, Judson I (2008) Phase I pharmacokinetic and pharmacodynamic study of the oral mammalian target of rapamycin inhibitor everolimus in patients with advanced solid tumors. J Clin Oncol 26: 1588-1595

Panwalkar A, Verstovsek S, Giles FJ (2004) Mammalian target of rapamycin inhibition as therapy for hematologic malignancies. Cancer 100: 657-666

Scott KL, Kabbarah O, Liang MC, Ivanova E, Anagnostou V, Wu J, Dhakal S, Wu M, Chen S, Feinberg T, Huang J, Saci A, Widlund HR, Fisher DE, Xiao Y, Rimm DL, Protopopov A, Wong KK, Chin L (2009) GOLPH3 modulates mTOR signalling and rapamycin sensitivity in cancer. Nature 459: 1085-1090

Sparks CA, Guertin DA (2010) Targeting mTOR: prospects for mTOR complex 2 inhibitors in cancer therapy. Oncogene 29: 3733-3744

Tabernero J, Rojo F, Calvo E, Burris H, Judson I, Hazell K, Martinelli E, Ramon y Cajal S, Jones S, Vidal L, Shand N, Macarulla T, Ramos FJ, Dimitrijevic S, Zoellner U, Tang P, Stumm M, Lane HA, Lebwohl D, Baselga J (2008) Dose- and schedule-dependent inhibition of the mammalian target of rapamycin pathway with everolimus: a phase I tumor pharmacodynamic study in patients with advanced solid tumors. J Clin Oncol 26: 1603-1610

Tanaka C, O'Reilly T, Kovarik JM, Shand N, Hazell K, Judson I, Raymond E, Zumstein-Mecker S, Stephan C, Boulay A, Hattenberger M, Thomas G, Lane HA (2008) Identifying optimal biologic doses of everolimus (RAD001) in patients with cancer based on the modeling of preclinical and clinical pharmacokinetic and pharmacodynamic data. J Clin Oncol 26: $1596-1602$
Wolpin BM, Hezel AF, Abrams T, Blaszkowsky LS, Meyerhardt JA, Chan JA, Enzinger PC, Allen B, Clark JW, Ryan DP, Fuchs CS (2009) Oral mTOR inhibitor everolimus in patients with gemcitabine-refractory metastatic pancreatic cancer. J Clin Oncol 27: 193-198

Workman P, Aboagye EO, Balkwill F, Balmain A, Bruder G, Chaplin DJ, Double JA, Everitt J, Farningham DA, Glennie MJ, Kelland LR, Robinson V, Stratford IJ, Tozer GM, Watson S, Wedge SR, Eccles SA (2010) Guidelines for the welfare and use of animals in cancer research. Br J Cancer 102: 1555 - 1577

Wouters BG, Koritzinsky M (2008) Hypoxia signalling through mTOR and the unfolded protein response in cancer. Nat Rev Cancer 8: $851-864$

Yao JC, Phan AT, Chang DZ, Wolff RA, Hess K, Gupta S, Jacobs C, Mares JE, Landgraf AN, Rashid A, Meric-Bernstam F (2008) Efficacy of RAD001 (everolimus) and octreotide LAR in advanced low- to intermediate-grade neuroendocrine tumors: results of a phase II study. J Clin Oncol 26: $4311-4318$

Yee KW, Zeng Z, Konopleva M, Verstovsek S, Ravandi F, Ferrajoli A, Thomas D, Wierda W, Apostolidou E, Albitar M, O'Brien S, Andreeff M Giles FJ (2006) Phase I/II study of the mammalian target of rapamycin inhibitor everolimus (RAD001) in patients with relapsed or refractory hematologic malignancies. Clin Cancer Res 12: 5165-5173

Yoshioka A, Miyata H, Doki Y, Yasuda T, Yamasaki M, Motoori M, Okada K, Matsuyama J, Makari Y, Sohma I, Takiguchi S, Fujiwara Y, Monden M (2008) The activation of Akt during preoperative chemotherapy for esophageal cancer correlates with poor prognosis. Oncol Rep 19: $1099-1107$

This work is published under the standard license to publish agreement. After 12 months the work will become freely available and the license terms will switch to a Creative Commons Attribution-NonCommercial-Share Alike 3.0 Unported License. 